\title{
Cranial plasmacytoma as the presentation of relapsed multiple myeloma: a case report
}

\author{
Sanjeev KS*, Meet K, Dharma C, Divya D and Vipin K \\ Department of Hemato-oncology and Bone marrow Transplantation, BLK Superspeciality Hospital, New Delhi, India
}

\begin{abstract}
Multiple myeloma is a neoplastic disorder of plasma cells. Plasma cell neoplasms can present as a single lesion (solitary plasmacytoma) or as multiple lesions (multiple myeloma). Solitary plasmacytomas can occur in bone (plasmacytoma of bone), or in soft tissues (extramedullary plasmacytoma). The bone lesions are due to monoclonal or malignant plasma cell infiltration. After relapse the patient most commonly presents with medullary disease but occasionally can have extramedullary involvement.
\end{abstract}

\section{Introduction}

Multiple myeloma is a neoplastic disorder of plasma cells. Plasma cell neoplasms can present as a single lesion (solitary plasmacytoma) or as multiple lesions (multiple myeloma) [1]. Solitary plasmacytomas can occur in bone (plasmacytoma of bone), or in soft tissues (extramedullary plasmacytoma). The bone lesions are due to monoclonal or malignant plasma cell infiltration. After relapse the patient most commonly presents with medullary disease but occasionally can have extramedullary involvement. We present here a case of multiple myeloma who at the time of relapse developed large plasmacytoma of the skull.

\section{Case presentation}

A 68 years old female patient was diagnosed as a case of multiple myeloma 4 years back. She had received 4 cycles of Bortezomib/ Thalidomide/dexamethasone chemotherapy and had refused for autologous stem cell transplant. She presented with progressively increasing mass over the skull (Figure 1), further evaluation revealed relapse of multiple myeloma with serum protein electrophoresis showing $M$ band of $3.2 \mathrm{~g} / \mathrm{dl}$. Her hemoglobin was $8.1 \mathrm{~g} / \mathrm{dl}$. Her liver and kidney function profile were normal. She was treated with lenalidomide and dexamethasone therapy but did not have any clinically significant decrease in skull mass on follow-up. This case highlights the extramedullary manifestations of relapsed multiple myeloma.

\section{Discussion}

Myeloma is the most common plasma cell neoplasm. It presents clinically with serum monoclonal immunoglobulins (M protein), lytic bone lesions, anemia, renal impairment, and hypercalcemia $[1,2]$.

Extramedullary plasmacytomas can arise anywhere in the body. Definitive diagnosis requires fine needle aspiration or biopsy of the mass lesion. In a study, $7 \%$ of patients developed extramedullary involvement at the time of diagnosis and $6 \%$ of patients developed soft-tissue extramedullary plasmacytomas at 30-month follow-up [3]. Head and neck is the commonest site of plasma cell involvement

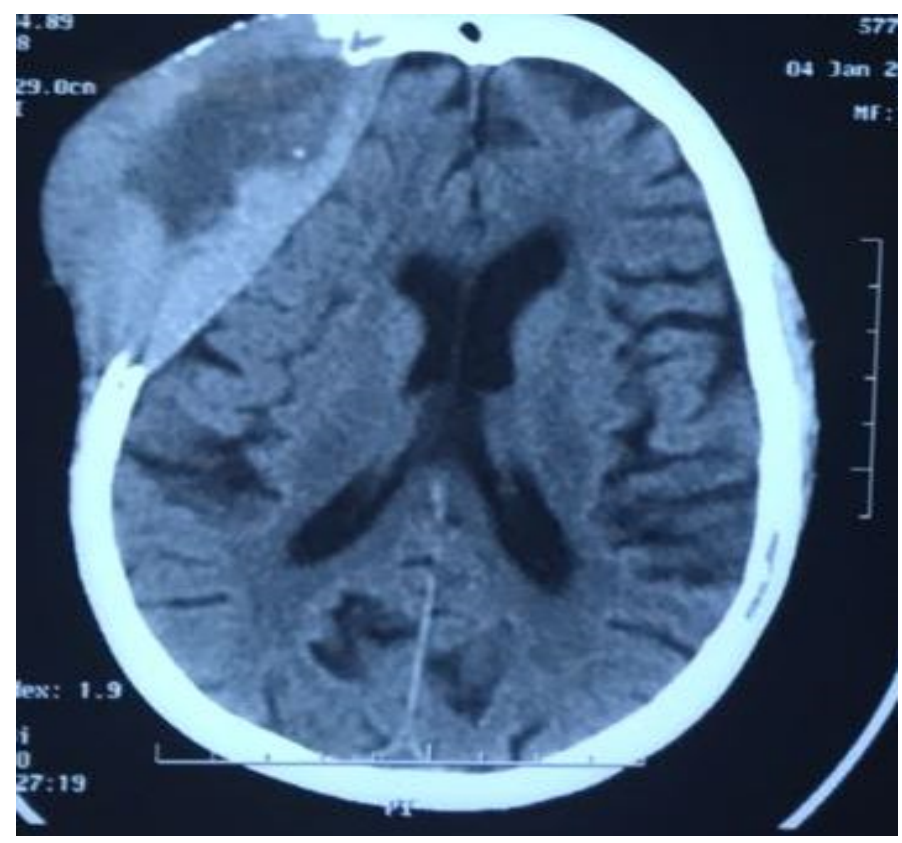

Figure 1. Computed tomography scan of head showing involvement of right frontal bone by plasmacytoma with extensive bone destruction. The lesion has an exophytic component and reveals multiple areas of calcifications along its periphery

[4]. Patients with extramedullary relapse have significantly shorter overall survival than patients without extramedullary relapse [5]. Radiotherapy is the treatment of choice for patients with solitary plasmacytoma but patients with associated myeloma with require systemic treatment as well.

${ }^{\star}$ Correspondence to: Sanjeev KS, Senior Consultant and HOD, Department of Hemato-oncology and Bone marrow Transplantation, BLK Superspeciality Hospital, New Delhi, India, E-mail: sksanjeev13@yahoo.com

Received: November 30, 2018; Accepted: December 12, 2018; Published: December 17, 2018 


\section{Conclusion}

Plasmacytoma can be the manifestation of multiple myeloma at presentation or at relapse. It should be suspected in any case of myeloma presenting with new onset mass lesions.

\section{References}

1. Soutar R, Lucraft H, Jackson G, Reece A, Bird J, et al. (2004) Guidelines on the diagnosis and management of solitary plasmacytoma of bone and solitary extramedullary plasmacytoma. Br J Haematol 124: 717-726. [Crossref]
2. Kumar SK, Therneau TM, Gertz MA, Lacy MQ, Dispenzieri A, et al. (2004) Clinical course of patients with relapsed multiple myeloma. Mayo Clin Proc 79: 867-874. [Crossref]

3. Madan S, Kumar S (2009) Review: extramedullary disease in multiple myeloma. Clin Adv Hematol Oncol 7: 802-804. [Crossref]

4. Wax MK, Yun KJ, Omar RA (1993) Extramedullary plasmacytomas of the head and neck. Otolaryngol Head Neck Surg 109: 877-885. [Crossref]

5. Pour L, Sevcikova S, Greslikova H, Kupska R, Majkova P, et al. (2014) Soft-tissue extramedullary multiple myeloma prognosis is significantly worse in comparison to bone-related extramedullary relapse. Haematologica 99: 360-364. [Crossref]

Copyright: $\odot 2018$ Sanjeev KS. This is an open-access article distributed under the terms of the Creative Commons Attribution License, which permits unrestricted use, distribution, and reproduction in any medium, provided the original author and source are credited. 